\title{
Disbursement and Recovery of Rural Credit: A Study on Rajapur Branch of Rupali Bank Limited
}

\author{
Nishad Nasrin ${ }^{1}$, Shankari Bala Sarker ${ }^{2}$ \\ ${ }^{l}$ (Assistant Professor, Economics Discipline, Khulna University, Khulna-9208, Bangladesh) \\ ${ }^{2}$ (Economics Discipline, Khulna University, Khulna-9208, Bangladesh)
}

\begin{abstract}
Financial institutions are the blood of an economy and basically works as an intermediary to regulate the circulation of money as well as to ensure their profitability by loan disbursement in different sectors. The main purpose of this paper is to find out the disbursement and recovery performance of rural credit of Rupali Bank Limited (RBL) in different sectors namely agriculture and industry. To attain the objective, mean difference t-test and econometric model are analyzed. For analysis, whole population is taken into account in which one group is loan taker of business sector and other is agricultural sector. The finding of t-test shows that the recovery performance of the business sector is superior to agricultural sector or in other words the agriculture sector has more problems in loan repayment than business sector. The econometric model is used to analyze the recovery performance of the bank. The robust standard error is used to remove all peculiarities in data. From the analysis, it is found that the coefficients age and education are not statistically significant but the two variables namely business type and income level are statistically significant. Family size is close to significant which indicates that the higher income group, fewer family members and disbursement of loan in business sector are related to higher recovery performance. This study is a model based approach to find out the recovery performance in different sectors. Therefore, it can be helpful to the bankers and policy makers of banking and financial institutions to select the right borrowers for disbursing loan and get better recovery from these sectors.
\end{abstract}

Keywords: Bank, rural credit, disbursement, recovery

\section{Introduction}

Bangladesh is a third world country with an under developed economic system and agriculture is the mainstay of Bangladesh economy being major contributor to the Gross Domestic Product (GDP). Special emphasis has been given by the Government and Bangladesh bank to patronize this sector. Like agriculture, emphasis has also been given to extend credit facilities to rural sector. It can bring about a change in economic development of the country particularly in rural areas through poverty reduction and employment generation. Rural credit also can be extended to the agro-based sector by extending credit facilities to agriculture sector for cultivation of crops, agro-based projects, etc. [1]. Recently the private banks are trying to imitate the banking structure of the more developed countries but this attempt is often foiled by inexpert or politically motivated policies executed by the central bank of Bangladesh named Bangladesh Bank. Today, commercial banks are regarded as instrument of economic growth with social justice. The development of sound commercial banking helps underdeveloped countries to join the ranks of advanced countries [2]. However, private banks as well as nationalized commercial banks and specialized banks play an important role through their proper credit disbursement system in different sectors and sub-sectors. Banks main function is to mobilize deposits from different sources and deploy this fund efficiently with safety and security to earn maximum profit complying with all regulatory requirements. Soundness of a bank is reflected in the distribution of its funds on different types of assets. The RBL has responsibility to ensure efficient and effective banking operation in a sound manner. The main purpose of credit system of RBL is to invest funds profitability with safety and security and maintaining liquidity in order to support and expand industrialization, trade, commerce and agriculture towards overall economic development of the country. The objective of the study is to evaluate the disbursement and recovery of rural credit in different sectors namely agriculture and industry of the Branch. Most credit needs of the society, for carrying commercial activities are fulfilled by the banks. To secure a better adaptation of the banking system to the needs of economic planning and it is playing a more active role in aiding priority sectors like agriculture and small-scale industry [3].

A prudent bank management should always try to make an appropriate balance between its return and risk involved with the loan assortment. Thus, recovery of commercial loan is a recurring worry for the bankers [4]. The banking sectors with few large, well capitalized banks are likely to generate better efficiency and higher rates of intermediation [5]. The important thing for financial institutions is to tailor services such that it becomes worthwhile for the poor to establish a profitable long-term association [6]. 
Islami Bank has made a positive contribution towards the socio-economic development of the country. Keeping this idea, the bank has prepared an integrated policies, methods and procedures for SME investment [7]. Commercial banks involve themselves in development financing through branch expansion, mobilization of savings, sectoral and regional distribution of advances, etc. [8]. The business environment of a developing economy has a significant impact on the profitability and performance of the banks. As a result, the whole macroeconomic and business environment has a significant impact on the profitability and performance of the banks [9]. Commercial banks have a strong appraisal system that allows few sectors to access credit and carry out little loan monitoring and follow up and experiencing lower levels of recovery leading to poor loan portfolio performance while micro finance though charging high interest rate have been experiencing higher loan recovery [10]. The real risk from credit is the deviation of portfolio performance from its expected value. Accordingly, credit risk is diversifiable, but difficult to eliminate completely. This is particularly true for banks that lend in local markets and take on highly illiquid assets. In such cases, the credit risk is not easily transferred, and accurate estimates of loss are difficult to obtain [11]. Personal installment loan services of foreign commercial banks are more dynamic, technological oriented and aggressive customer service than the local commercial bank [12]. The loan default of a bank depends on aggregate productivity and size of business sector. When aggregate productivity falls, net worth of banks falls because of an unexpected increase in loan default. [13]. Agriculture is life-blood of the rural economy employing 54\% of rural workers and its growth is crucial alleviation of poverty. The government organizations have taken several steps over the years to provide rural credit in general and to the farmers with middle size holdings through different financial intermediaries [14]. Bangladesh has been experimenting with a rural credit program for the extreme poor people. Like other financial institutions, Grameen bank also evaluates its credit operations and assesses the banks effect on poverty reduction [15]. The very visible activities or microfinance state are outreach and portfolio size, proliferation of microfinance through a large number of microfinance institutions, diversification of services, new regulatory regime, contribution in rural development, and recognition of microfinance and as a major contributor in poverty reduction [16]. Financial instruments and interbank investment of Islamic financial institutions would allow surplus banks to channel funds to deficit banks [17]. The Islamic financial systems especially the Islamic microfinance programs to provide the rural people with an opportunity by which they can improve their lives and overall livelihoods [18]. The micro finance investment system is being established an important impact in the form of increasing the income and reducing poverty style of the beneficiaries. It also helps potential women to be empowered in the society [19]. Ensuring access to credit in the rural areas for augmenting agricultural production, reducing poverty and improving the efficiency of the rural credit delivery system has been an area of focus in the planning process in our country [20]. Grameen bank and BRAC works for reduction of poverty by empowering women through providing credit to poor rural women in Bangladesh [21]. The main objective of the rural credit policy and programs of the bank have been designed to cover all segments of rural population whether skilled or unskilled such as farmers, landless, laborers, women, unemployment educated and vocational trained youths, weavers, and other rural dwellers and artisan. A good number of micro credit programs have been launched for poverty reduction sponsored by the bank on its own and in collaboration with local and foreign agencies [22]. The existing evidence on the impact of micro credit on poverty in Bangladesh is not clear-cut but access to credit has the potential to significantly reduce poverty [23]. Micro credit reduces vulnerability through strengthening crisis-coping mechanisms, diversifying income-earning sources, building assets and improving the status of women [24]. Micro, small, and medium-size enterprises (MSMEs) and marginal, small, and medium-size farmers (MSMFs) are the engines of growth in rural Bangladesh. The access to bank credit increases with farm size, while access to microcredit decreases but the average loan per acre declines with increasing farm acreage [25]. The informal sector is competitive, and that high interest rates reflect high information costs, not the scarcity of funds [26]. Government provides rural credit through formal and informal institutions. Though not aimed specifically at poverty alleviation, it has a tremendous impact on rural income generating activities [27]. Credit risk is the largest and most obvious source of risk in banking and it comes from a bank's credit portfolio but one of the goals of credit risk management in banks is to maximize a bank's risk-adjusted rate of return by maintaining credit risk exposure within the acceptance level [28].

The existing works regarding the issues of disbursement and recovery of rural credit are not sufficient to analyze the present condition of performance of banks. Most of the researchers have studied on general banking system, total performance of loans and advances system, customer satisfaction level, credit management system and total recovery rate of a bank. Therefore, all the work is related to the topic disbursement and recovery of rural credit. Three-fourth of the people lives in rural area and they are relatively poor. Bangladesh bank has already taken several steps to improve the living condition of rural people through disbursement of rural credit that can enhance the business and other sectors of an economy. Still there have no model based in depth work on disbursement and recovery of rural credit of RBL in Khulna region of Bangladesh. For this reason the study is interested to work on disbursement and recovery of rural credit. 


\section{Methodology}

Rajapur branch of RBL is the study branch and this is primary and secondary data based research. In the study area, total population is taken account for this research. Data have been collected from debtors who take loan from RBL. Some debtors use loan for agricultural purposes and some use for business purposes. These two types of users are taken as population in this study. Total population size is 110, among them population 57 are business, and 53 are agriculture. The study is a quantitative and descriptive as well as analytical research by nature. Qualitative analysis is concerned with qualitative phenomena and it is primarily used in behavioral science which is not use in this thesis [29]. It is also an analytical research because $t$-test and regression analysis are used in this research for disbursement and recovery of rural credit analysis. To analysis the disbursement and recovery of rural credit the statistical tools like $t$ test and multiple regression models are used in the research.

\subsection{Tools of analysis}

\subsubsection{Mean difference $t$ test}

To find out the significance level between agriculture and business $t$ test is used. The $t$ test helps to know the profitable sector for investment. Through $t$ test analysis, it will be clear that the recovery performance of rural credit at agricultural sector and business which help to evaluate the rural credit management system of RBL.

Where, $H_{o}: \mu_{1}=0 \leftarrow$ Null hypothesis

It implies that there is no significant mean difference between loan recovery from agriculture and business. If calculated $t$ value is larger than the tabulated $t$ value than null hypothesis is rejected.

\subsubsection{Specification of the regression model}

The purpose of the study is to estimate the disbursement and recovery of rural credit of RBL. To meet up the purpose the author takes regression analysis. This function plays an important role in economic research. To measure the recovery performance this function is used. In the research the dependent variable recovery depend on more independent variable like age, education, family size, business type and income. The regression form for the rate of recovery of rural credit is specified as:

$$
Y_{\text {recy }}=b_{0}+b_{1} X_{1}+b_{2} X_{2}+b_{3} X_{3}+b_{4} X_{4}+b_{5} X_{5}+u_{i}
$$

Where, $u_{i}=$ Error term

$b_{o}=$ Constant

$b_{1} \ldots \ldots . b_{5}=$ Co-efficient of respective variables

Table 2.1: Description of the variables and measurement unit

\begin{tabular}{|c|c|c|c|}
\hline Description of the Variables & Measurement Unit & Expected Sign & Supporting Literatures \\
\hline Recovery $\left(Y_{\text {recy }}\right)$ & BDT & $(+)$ & {$[30]$} \\
\hline Age $\left(X_{I}\right)$ & Age in Years & $(-)$ & Author's Compilation \\
\hline Education of the Debtor $\left(X_{2}\right)$ & Years of Schooling & $(+)$ & {$[31]$} \\
\hline Family Size of the Debtor $\left(\mathrm{X}_{3}\right)$ & Number of Family Member & $(-)$ & {$[32]$} \\
\hline \multirow[t]{3}{*}{ Business Type $\left(X_{4}\right)$} & Dummy Variable for & $(+)$ & [33] \\
\hline & Agricultural Sector Taking 0 and & & \\
\hline & Business Sector Taking 1 & & \\
\hline Income of the Debtor $\left(X_{5}\right)$ & BDT & $(+)$ & [34] \\
\hline
\end{tabular}

Source: Author's Compilation, 2014

\subsection{Age pattern}

\section{Analysis And Discussion}

Age is considered as a very imperative element for involving in economic activities. Most of the debtors are between the age ranges of 41-50, this range shows that the middle aged people taking more loan from the concerned branch. The age range of 31-40 is considerably 35 percent of the loan taker. 
Figure 3.1: Age pattern of the loan takers

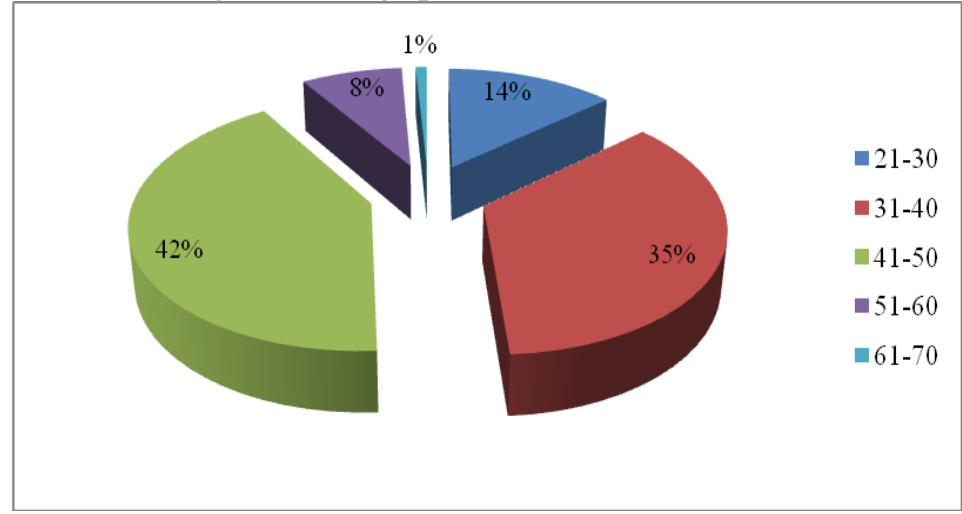

Source: Author's Compilation based on field survey, 2014

The Fig. 3.1 shows that this age range includes around 42 percent of the total respondents while bellow 30 years and above 60 years.

\subsection{Sex structure}

Most of the respondents in this study are male and they involve in different types business activities but only around 10 percent are female debtor, which is shown in Fig. 3.2.

Figure 3.2: Sex Structure of the loan takers

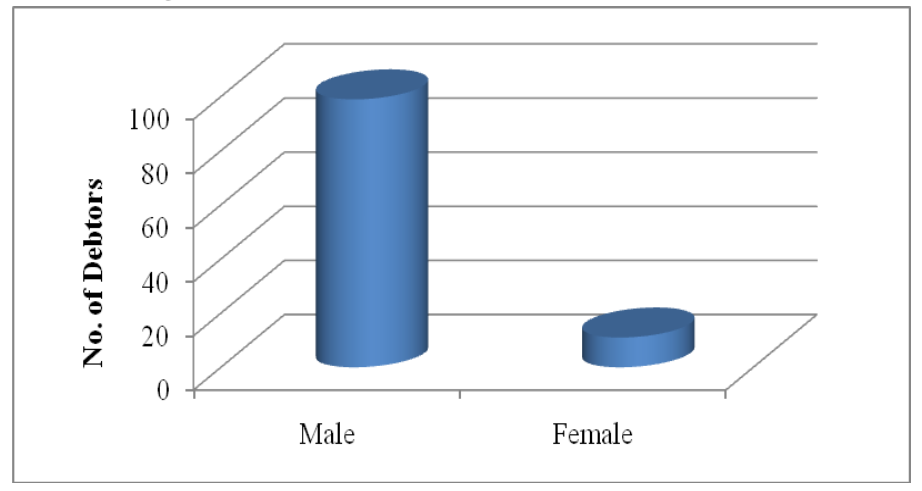

Source: Author's Compilation based on field survey, 2014

In the study area among 110 debtors 99 debtors are male and only 11 debtors are female.

\subsection{Educational Status}

The educational status of the debtors is not good because most of them live in village where literacy rate is low. So, most of them are under secondary level, S.S.C and H.S.C level educated. More than around 37 percent people are secondary educated in the survey area and only around 8 percent people are graduated but S.S.C and H.S.C pass people are comparatively low.

Figure 3.3: Educational status of loan takers

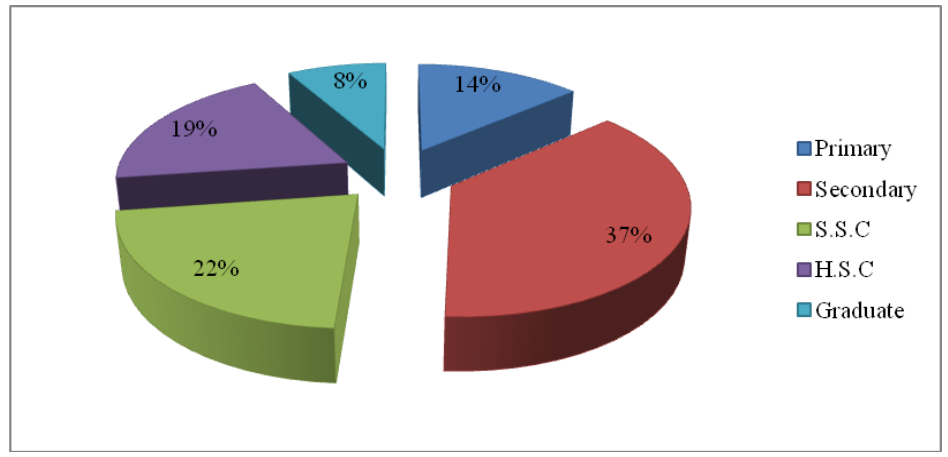

Source: Author's Compilation based on field survey, 2014 
In Fig. 3.3, it can be seen that the percentages of them are respectively around 22 percent and around 19 percent. From the analysis of education it is found that, though most of the debtors are not illiterate but they are also not highly educated. Most of the respondents are under secondary and S.S.C level.

\subsection{Sector wise disbursement of rural credit}

The rural people are poor and lower educated. So, they take loan for small business. Here, the business type is divided into two types; agricultural and business. In this study there is a small difference between the loan taker for agricultural and business activities

Figure 3.4: Sector wise disbursement of rural credit

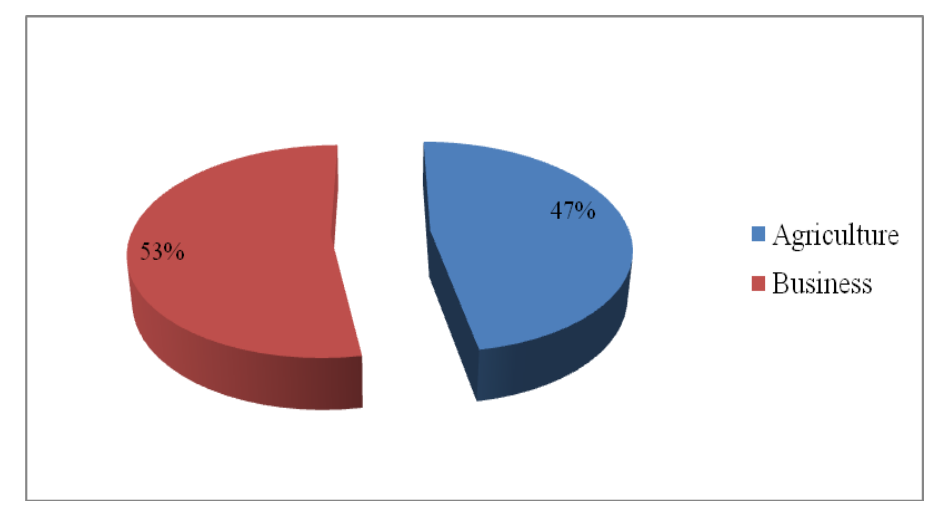

Source: Author's Compilation based on field survey, 2014

From the Fig. 3.4 , it is found that out of 110 respondents around 47 percent are have taken loan for agricultural activities and 53 percent are have taken loan for business activities. The disbursement of rural credit at business sector is higher than at agricultural sector.

\subsection{Interest rate on rural credit of RBL and other banks}

The interest rate of RBL and other three nationalized bank such as Sonali, Agroni and Janata Bank is determined by Bangladesh Bank. The interest rate on rural credit of RBL is only 12 percent.

Figure 3.5: Interest rate of RBL and other banks

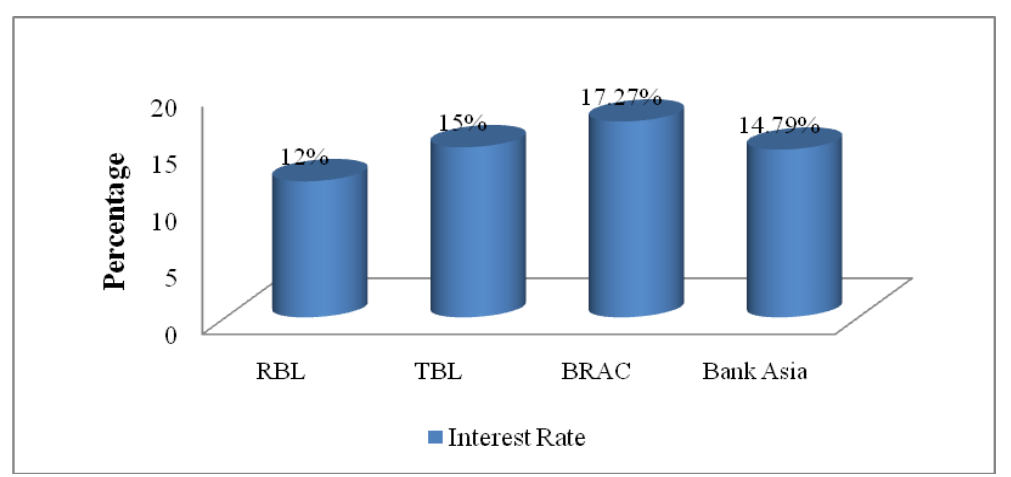

Source: Author's Compilation based on field survey, 2014

Fig. 3.5 provides the interest rate of RBL and other bank in Bangladesh. Among RBL, Trust Bank Limited, BRAC Bank and Bank Asia, interest rate provided by BRAC Bank (17.27 percent) is the highest where as RBL provide lowest interest rate than other banks. The interest rate of RBL is only 12 percent. So, the interest rate of RBL on rural credit does not effect on the recovery of rural credit.

\subsection{Disbursement and recovery of rural credit}

In Bangladesh, Micro lenders in the financial field are working and providing very small amount and on the other hand regular commercial bank have been providing bigger amount of loans to larger industries and trading organizations. On the other hand, the loan recovery unit established in the branch and zonal office ascertain the statements of the loans advances as sub-standard. In case of doubtful and bad debts as the case may be as per guidelines of Bangladesh Bank, the authority takes steps and at this stage, normal steps like physical 
contact with the borrower and through letters requesting to take steps for adjustment and renewal. Total disbursement and recovery from 2013 to 2014 of RBL of Rajapur branch are given in Table 3.1.

Table 3.1: Disbursement, recovery and recovery rate of rural credit

\begin{tabular}{rrrr}
\hline Year (Closing Date) & Total Disbursement (in BDT) & Total Recovery (in BDT) & Recovery Rate in Percentage \\
\hline Jun 30, 2013 & $2,002,408$ & 2,00000 & 9.47 \\
Dec 30, 2013 & $1,911,353$ & 3,50000 & 18.31 \\
Jun 30, 2014 & $4,698,000$ & 2935700 & 62.49 \\
\hline
\end{tabular}

Source: Author's Compilation Based on Field Survey, 2014

From the analysis of the Table no. 3.1 it is found that, the recovery rate of rural credit of this branch is very low. However, this rate increases progressively. In June 30, 2013 the recovery rate was only 9.47 percent but in June 30, 2014 it increases and become 62.49 percent. Due to consciousness of the debtors and regular supervision of the bankers, the rate increases gradually but this rate is not satisfactory. If the recovery rate is more than 90 percent, then this rate is called 'satisfactory rate'.

\subsection{Interpretation of mean difference $t$-test}

To find out the significance level between agriculture and business $t$ test is used. The $t$ test helps to know the profitable sector for investment. The respondents of the survey area take loan for the purposes of agricultural activities and business activities. Here, assume the null hypothesis: there is no significant mean difference between loan recovery from agriculture and business. Now the $t$ test is given in Table 3.2.

Table 3.2: Estimated value of $t$-test

\begin{tabular}{rrrrrr}
\hline Variable & Observation & Mean & Std. Err. & Std. Dev. & $t$ \\
\hline Agriculture & 53 & 17447.17 & 2803.028 & 20406.35 & \\
Business & 57 & 35280.70 & 1601.565 & 12091.55 & \\
combined & 110 & 26688.18 & 1793.69 & 18812.38 & -5.6224 \\
\hline diff & & -17833.53 & 3171.889 & &
\end{tabular}

Source: Author's Compilation Based on Field Survey, 2014

From the Table 3.2, it is found that, at 1 percent significant level the tabulated $t$ value is \pm 2.58 but calculated $t$-value is -5.6224 . So, we reject the null hypothesis and conclude that the mean difference between recovery of agricultural and business sector is statistically significant. It means that the recovery performance of the business sector is better than agricultural sector.

\subsection{Regression model and discussion}

In this study to find out the recovery performance the authors perform a regression analysis using the variables recovery, age, education, family size, business type and income (Table 3.3). These measure the recovery performance of the bank (recovery), the age size (age), the year of schooling (education), the number of family member (family size), the dummy variable $(0=$ agriculture and $1=$ business $)$ is (business type) and monthly income in BDT (income). Here expect that better recovery performance would be associated with lower age group, higher educated people, fewer family members, disbursement loan to the business sector and higher income group people. Table 3.3 shows the STATA command for testing this regression model followed by the STATA output. From the result it is clear that the coefficient of age, education and family size are not statistically significant so that quantity of variables cannot explain the recovery along. The $\mathrm{R}^{2}$ value is 0.63 that means 63 percent variation of recovery (for detail see Annex I, Table 1). The explanatory variables can explain 0.63 percent of the variation of dependent variable. Let us, focus on the five predictors, whether they are statistically significant and, if so, the direction of the relationship. In this model, variance inflation factor and heterosscedasticity is analyzed and then include the robust standard error in main text for removing all vulnerabilities in data. 
Table 3.3: Estimated value of regression model

\begin{tabular}{lc}
\hline \multirow{2}{*}{ VARIABLES } & OLS \\
\hline \multirow{2}{*}{ Age } & 33.13 \\
& $(105.7)$ \\
Education & 102.8 \\
Family Size & $(370.2)$ \\
& $-1,376$ \\
Business Type & $(963.3)$ \\
& $6,756^{* *}$ \\
Income & $(2,698)$ \\
& $5.463 * * *$ \\
Constant & $(0.763)$ \\
& $-16,210$ \\
Observations & $(10,314)$ \\
R-squared & 110 \\
\multicolumn{2}{c}{ Robust standard errors in parentheses } \\
Source: Author's estimation Based on Field Survey, 2014
\end{tabular}

The age size (age, $b=33.13$ ), is not statistically significant at the 0.05 level $(p=0.755)$, but only just so. The coefficient is positive which indicates that higher age size is related to better recovery performance, which is not expected. In this study area, the higher age groups are involved in different types of job. As a result, their recovery performance is better than the lower age group. After that, the effect of education (education $b=$ 102.78, $\mathrm{p}=0.782$ ) is not significant but its coefficient is positive indicating that the recovery performance of higher educated group is better than lower educated group for recovery of loan and this result is expected. In the study area, most of the debtors live in rural area, so they have little knowledge about loan recovery, but the higher educated people are much aware about loan recovery. Therefore, they pay their monthly installment regularly. Now, the effect of family size (family size, $b=-1376.25, p=0.156$ ) which is close to statistically significant for robust standard error but the result statistically not significant. This seems to indicate that the number of family member is an important factor in predicting recovery performance. The coefficient is negative which indicates that small family size is related to better recovery performance that is expected. If the family size is small then their expenditure also low. Therefore, they can save money and pay their monthly installment regularly. Later, the result of business type (business type, $b=6755.71, p=0.014$ ) is statistically significant at 5 percent level and its coefficient is positive indicating that the recovery performance of the business sector is superior to the agricultural sector. It indicates that, if the occupation is business than the recovery is about 6756 Taka more than that of profession agriculture. In business sector, the loan recovery performance is better than the agricultural sector. The probable reason may be the loan takers invest their loan for business purposes and earn profit from their investment. The debtors who take loan for agricultural purposes cannot able to repay their monthly installment regularly because every year several types of natural disasters hamper their production and use of loan in consumption purposes. Finally, the monthly income of the debtor (income, $b=5.46, p=0.000$ ) is statistically significant at 1 percent level and the coefficient is positive which indicates that the higher income group is related to better recovery performance. If the income of the debtors increases by BDT 1, than recovery increases about BDT 5.5, which is statistically significant. The higher income group people can save money and pay their debt regularly. So, the income variable is highly related to better recovery performance.

From these results, it can be concluded that the higher income group and disbursement of loan in business sector are related to higher recovery performance. Family size is close to statistically significant so, it also related to better recovery performance. On the other hand, the age groups and year of schooling are not related to better recovery performance as insignificant is shown in the result. The RBL of Rajapur branch is suffered significant loan repayment default. There are many reasons behind loan recovery such as the repayment period of rural credit is only two years. Thus, debtors are failed to repay the loan within satisfactory time. Income is another factor which influences loan recovery. Most of the people of this study area are live in rural area and not higher educated. Therefore, their income is as low as to repay the loan. Business type is another cause for loan default. The people who take loan for agricultural purposes cannot able to recover the loan on time because every year several types of natural disasters such as cyclone, flood, drought, flash flood, over rainfall etc. hamper their crops and livestock. Besides these, lack of monitoring of loan at branch level is another cause of loan default. 


\section{Concluding Remarks}

RBL is one of the leading commercial banks and it has various divisions to perform various activities. The credit department now performs relatively better than previous as they have batter but precious information about this. It is also smooth in processing the necessary investment documents and in sanctioning credit or investment to the customers. It is found that, the relationship between customers and employees is good in all cases. Bank plays a very vital role for the development of the national economy of a country but, in giving loans to different sectors more analysis is necessary to get better performance from the bank perspective. There are some limitations in this paper, from them most vital is that there were some other variables that could be introduced but data unavailability and missing data made the effort as failure. The area is basically agro based but many industries ans small businesses are there in the study area. They take loan without maintaining proper rules and regulations of the bank in many cases for their personal interest and relationship. The most of the loan are used in bad sectors and consumption purposes. Thus, most of the loan is turned into bad loans. The authors have found that, in this branch this scenario was occurred previously. Only a few numbers of debtors are highly educated who have proper knowledge about loan recovery and the rest numbers of debtors have a little knowledge about the rules and regulations of the bank. One of the main findings is the participation of women in taking loan from bank is very low than the male population. It indicates that less percentage of the women is engaged in business activities. The age group of the debtors is another factor to recovery the loan. In this study area the higher age size group are involve in different types of job. As a result, their recovery performance is better than the lower age group. The Rajapur branch provides rural credit to agricultural sector and business sector. In this study from mean difference $t$ test shows that, the recovery performance at the business sector is better than to the agricultural sector. In this branch, the loan recovery performance of initial period is superior to ending period of the year. From the analysis of regression it is seen that, the recovery performance of higher age group, higher educated people and higher income group is relatively high. The small family size is related to better recovery performance because the expenditure of the small family is lower than the larger family size. From the analysis it is found that, the two variable income and business are statistically significant and family size is close to statistically significant for robust standard error this indicates that the higher income group and disbursement of loan to business sector and fewer family members are related to higher recovery performance. On the other hand, the age groups and education are not statistically significant so, these are not related to better recovery performance. It has also seen that the branch manager has no power to sanction a loan more than a certain level without the permission of the head office. The paper is done in a small scale area and that is why the scope is also limited in a small scale. There is further scope of intensive study. Even then the study is a model based approach which can help the policy makers and banking sectors as well.

\section{References}

[1] K.M.S. Rahman, General Credit and International Trade: Import and Export Financing, $2^{\text {nd }}$ edition (Center for Research on Banking and Human Research Development, 2013).

[2] K.M.S. Rahman, General Banking Practice and Law of Banking, $2^{\text {nd }}$ edition (Centre for Research on Banking and Human Research Development, 2013).

[3] R. Uppal, Priority Sector Advances: Trends, Issues and Strategies, journal of Accounting and Taxation, 1(5), 2009, 079-089.

[4] E. Ahmed, Z. Rahman, and R.I. Ahmed, Comperative Analysis of Loan Recovery Among Nationalized, Private and Islamic Commercial Banks of Bangladesh, Journal of Islamic Economics, Banking and Finance, 2006.

[5] D.A. Grigorian, and V. Manole, Determinants of Commercial Bank Performance in Transition: an Application of Data Envelopment Analysis, World Bank Policy Research, Working Paper, 2850, 2002.

[6] M. Sharma, and M. Zeller, Repayment Performance in Group-based Credit Programs in Bangladesh: An Empirical Analysis, World Development, 25(10), 1731-1742, 1997.

[7] S. Haque, The Banking Practices and General Banking Functions under Al-arafah Islami Bank Ltd. Bangladesh, 2012.

[8] S. Saha, and M.S.K. Chowdhury, Role of Commercial Banks in Development Financing in Bangladesh, Bank Parikrama, 103-141, 2000 .

[9] A. Khandker, Commercial Banking in Developing Economy: A Case Study of Ten Private Commercial Banks of Bangladesh, 2014.

[10] K. Pafula, Financial Institutions Loan Portfolio Performance in Uganda. A Comparative Study of Commercial Banks and Micrifinance Institutions, Mekerere University Business School, 2003.

[11] A.M. Santomero, Commercial Bank Risk Management: an Analysis of the Process, Journal of Financial Services Research, 12(2-3), 1997, 83-115.

[12] M. Shamsuddoha, Personal Loan: Comparative Analysis between a Local and Foreign Bank in Bangladesh, ResearchGate, 2009.

[13] T. Takamura, A General Equilibrium Model with Banks and Default on Loans in (in English): Bank of Canada, Working Paper, 2013.

[14] R. Faruqee, Micro-Finance for Agriculture in Bangladesh: Current Status and Future Potential, Working paper no. o8, Microfinance institution, 2010.

[15] M. Hossain, Credit for Alleviation of Rural Poverty: The Grameen Bank in Bangladesh, International Food Policy Research Institute, 1988 .

[16] D.H. Alamgir, State of Microfinance in Bangladesh, Dhaka, As Part of the Project on State of Microfinance in SAARC Countries, Institute of Microfinance (InM), 2009. URL: http://www. inm. org. bd/publication/state_of_micro/Bangladesh. pdf. Institute of Microfinance (InM)

[17] S.M. Arman, Islamic interbank money market in bangladesh: a literature review, Kuwait Chapter of Arabian Journal of Business and Management Review, 2013, 2(9). 
[18] M.A. Ashraf, Attitudinal Dynamics for the Rural Poor toward Participation in MFIs in Bangladesh: Implications for Islamic MFIs, Developing Country Studies, 4(11), 2014, 110-124.

[19] T. Jinan, Impact of Micro-Investment Program under Rural Development Scheme of Islami Bank Bangladesh Limited for Poverty Alleviation in Mymensingh District, Thoughts on Economics, 19(4), 2014.

[20] V. Puhazhendhi, and B. Jayaraman, Rural Credit Delivery: Performance and Challenges before Banks, Economic and Political Weekly, 1999, pp. 175-182.

[21] S.M. Hashemi, S.R. Schuler, and A.P Riley, Rural Credit Programs and Women's Empowerment in Bangladesh, World development, 24(4), 1996, 635-653.

[22] M. Hossain, Credit for Alleviation of Rural Poverty: The Grameen Bank in Bangladesh, Tropicultura, 11(3), 1993, pp. 115-121.

[23] C. Meslier-Crouzille, E. Nys, and A. Sauviat, Contribution of Rural Banks to Regional Economic Development: Evidence from the Philippines, Regional Studies, 46(6), 2012, 775-791.

[24] H. Zaman, Assessing the Poverty and Vulnerability Impact of Micro-credit in Bangladesh: A Case Study of BRAC, 1999.

[25] A. Ferrari, Increasing Access to Rural Finance in Bangladesh: the Forgotten " Missing Middle", (World Bank Publications, 2008).

[26] A. Siamwalla, C. Pinthong, N. Poapongsakorn, P. Satsanguan, P. Nettayarak, W. Mingmaneenakin and Y. Tubpun, The Thai Rural Credit System: Public Subsidies, Private Information, and Segmented Markets, The World Bank Economic Review, 4(3), 1990, 271-295.

[27] M. Hannan, Rural Credit: An Assessment of Sources and Types Available in Bangladesh, Information Bulletin, $11,1996$.

[28] M.S. Rahman, Credit Risk Management Practices in Banks: An Appreciation, 2014.

[29] C. R. Kothari, Research Methodology, Methods and Techniques, $2^{\text {nd }}$ edition (New Dellhi, New Age International Limited, 2011).

[30] M.M. Rahman, M. Jafrullah, and A.T. Islam, Rural Development Scheme of Islami Bank Bangladesh Limited (IBBL): Assessment and Challenges, International Journal of Economics, Management and Accounting, 16(2), 2008.

[31] T. Jinan, Impact of Micro-Investment Program under Rural Development Scheme of Islami Bank Bangladesh Limited for Poverty Alleviation in Mymensingh District, 19(4), 2014.

[32] T. Jinan, Impact of Micro-Investment Program under Rural Development Scheme of Islami Bank Bangladesh Limited for Poverty Alleviation in Mymensingh District, 19(4), 2014.

[33] M.M. Rahman, M. Jafrullah, and A.T. Islam, Rural Development Scheme of Islami Bank Bangladesh Limited (IBBL): Assessment and Challenges, International Journal of Economics, Management and Accounting, 16(2), 2008.

[34] T. Jinan, Impact of Micro-Investment Program under Rural Development Scheme of Islami Bank Bangladesh Limited for Poverty Alleviation in Mymensingh District, 19(4), 2014.

\section{ANNEX I}

Table 01: Estimated value of regression model

\begin{tabular}{|c|c|c|c|c|c|c|}
\hline Variables & Coef. & Robust Std. & $\mathbf{t}$ & $\mathbf{P}>t$ & \multicolumn{2}{|c|}{ [95\% Conf. Interval] } \\
\hline Age & 33.1256 & 105.7441 & 0.31 & 0.755 & -176.5689 & 242.8201 \\
\hline Education & 102.7773 & 370.1903 & 0.28 & 0.782 & -631.3239 & 836.8785 \\
\hline Family Size & -1376.249 & 963.2713 & -1.43 & 0.156 & -3286.452 & 533.9543 \\
\hline Business Type & 6755.704 & 2698.386 & 2.50 & 0.014 & 1404.702 & 12106.71 \\
\hline Income & 5.463138 & .7631762 & 7.16 & 0.000 & 3.949731 & 6.976545 \\
\hline _cons & -16209.91 & 10314.36 & -1.57 & 0.119 & -36663.67 & 4243.844 \\
\hline Number of Observations & & 110 & & & & \\
\hline $\mathrm{F}(5,104)$ & & 23.17 & & & & \\
\hline Prob $>F$ & & 0.0000 & & & & \\
\hline $\mathrm{R}$-squared & & 0.6320 & & & & \\
\hline Root MSE & & 11710 & & & & \\
\hline
\end{tabular}

Source: Author's Compilation Based on Field Survey, 2014 